\title{
An Investigation of Damage Factors in Industrial Scale of Light-Weight Bricks Production
}

\author{
Kiki Dwi Wulandari ${ }^{1, *}$, and Januarti Jaya Ekaputri ${ }^{1,2}$ \\ ${ }^{1}$ Civil Engineering Department, Faculty of Civil Engineering and Planning, Institut Teknologi \\ Sepuluh Nopember (ITS), Indonesia \\ ${ }^{2}$ Konsorsium Riset Geopolimer Indonesia (KORIGI), Laboratorium Beton dan Bahan Bangunan, \\ 60111 Kampus ITS Sukolilo Surabaya, Indonesia
}

\begin{abstract}
A damage case of light weight brick's production approximately at $6-7 \%$ of total production was found daily in one industry in East Jawa, Indonesia. The physical damage of product always occured. This paper investigates some factors that affect the lost in laboratory analysis. The analysis includes the chemical analysis of raw materials, reactivity of pozzolanic materials, and observation of strength based upon the position of light-weight bricks during autoclaving process. In addition, fly ash is introduced as mineral additive as one of the alternatives to improve the product's quality. It is also concluded that grinding the silica sands particles is the optimum way to improve the quality, but the adding class $\mathrm{F}$ of fly ash to five percent in mixture is the most effective solution. Furthermore, maintaining quality of raw materials, curing process, and maintaining the machine will either reduce the product damage that occurred during the fabrication process in industry.
\end{abstract}

\section{Introduction}

Light-weight bricks usually called Autoclaved Aerated Concrete (AAC) is normally manufactured from siliceous materials (quartz-rich sand), calcareous materials (lime and cement) and calcium sulphate with traces of aluminium powder as foaming agent to produce porous [1-6]. These components are mixed with water under saturated steam pressure includes the hydrothermal treatment process at high-temperature (typical, $180^{\circ}$ $200^{\circ} \mathrm{C}$ ) for several hours $[4,5,7]$. The foaming agent reacts with calcium hydroxide or alkali to form hydrogen gas bubbles, then it contributes to produce high porosity in AAC $[1,6]$. A damage case of light weight brick's production approximately at $6-7 \%$ of total production was found daily in one industry in East Jawa, Indonesia. The physical damages that were occurred during AAC productions as illustrated in Fig. 1-3.

\footnotetext{
${ }^{*}$ Corresponding author: kiki.dwi.wulandari@gmail.com
} 


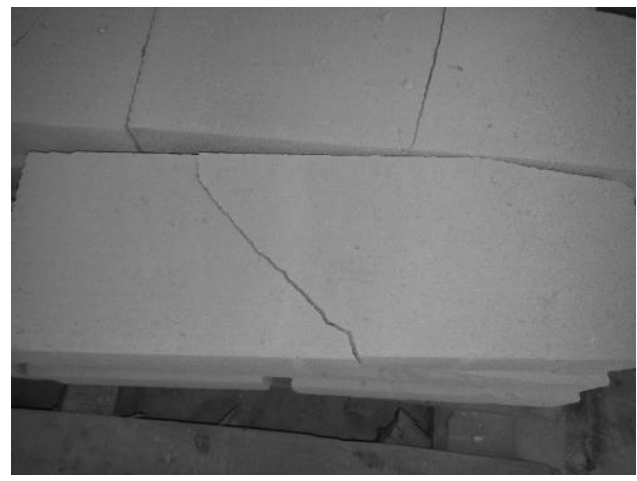

Fig. 1. Crack of AAC.

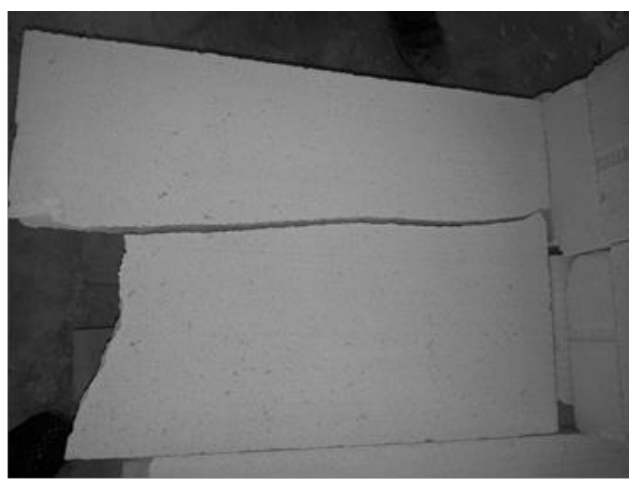

Fig. 2. Unsymmetrical shape of AAC.

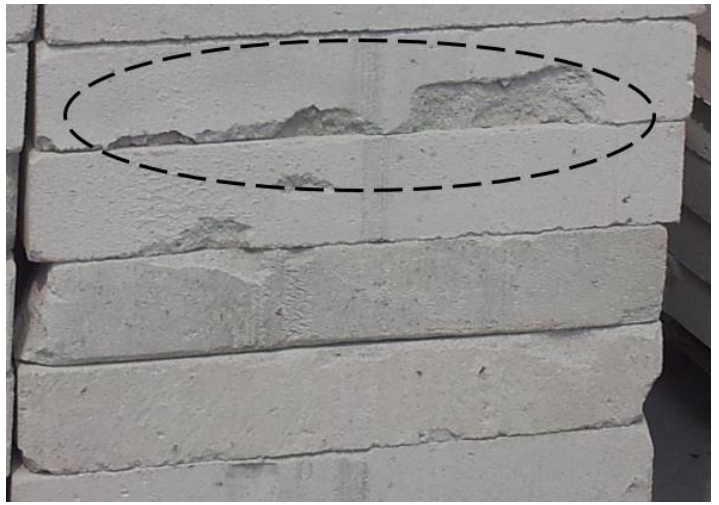

Fig. 3. Edge crack of AAC caused by re-bond after cutting process.

The physical properties of AAC are influenced by its structure, mineralogical composition, and texture. The structure of AAC can be set up by control the addition of foaming agent. Even so, mineralogical composition and texture of AAC, depend on composition and reactivity of raw materials [6]. The influence of mineral composition of raw materials was studied by many authors $[1,2,3,4,6,8,9,10]$. This paper investigates some factors that affect the damage case in laboratory analysis. It may involve some further analysis, both mechanical and physical. The analysis includes the chemical analysis of raw materials, reactivity of pozzolanic materials, and observation of strength based upon the position of light-weight bricks during autoclaving process. 


\section{Materials}

Raw materials in this research were obtained from two industries in East Jawa Indonesia. Silica sand SS, gypsum GY, lime CA, and aluminum powder AP, from light-weight brick's industry. The materials were collected in four batches. A class F of Fly Ash was collected from a fertilizer factory in East Jawa, Indonesia. The name of materials was based on their sources and batches.

\section{Experimental Test}

X-Ray Fluoressence (XRF) and X-Ray Difractometer (XRD) were set up to analyze the chemical composition oxides, and mineral content, respectively in all raw materials. Reactivity test was conducted to analyze the reactivity of pozzolanic materials, based on ASTM C 593-95. The reactivity analyses were applied to silica sands and fly ash. The best silica sand was grinding and compared with fly ash to replace the ordinary silica sand by $5 \%, 10 \%$, and $15 \%$, then reactivity test were conducted to analyze each other. While the compressive strength were observed based on the distribution of light-weight bricks in autoclave machine were observed at 28 days. Specimens were collected from four autoclaves in different position. They were picked up from upside, center, and below-side $(\mathrm{A}, \mathrm{B}$, and $\mathrm{C})$, and closed to the autoclave machine door, center, and backside $(\mathrm{D}, \mathrm{T}$, and B), as Fig. 4 below. For each block, there were five specimens $(60 \mathrm{~cm}$ x $20 \mathrm{~cm}$ x $10 \mathrm{~cm}$ per specimens). Compressive strength test were applied to two specimens which were chosen separately by the same block notation. It means there were 18 specimens for each autoclave.
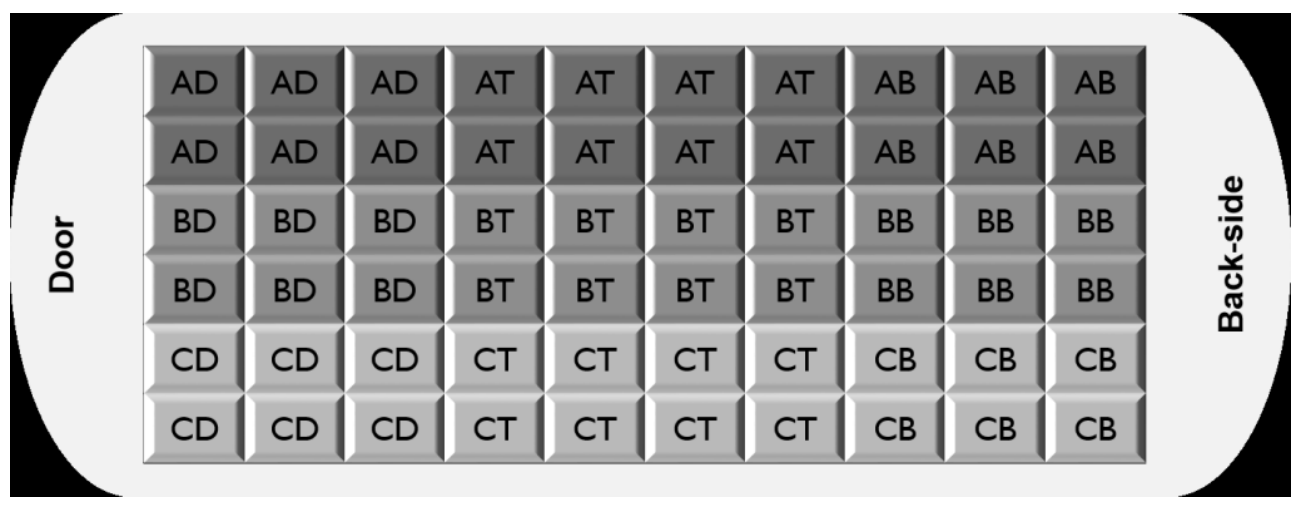

Fig. 4. Identification of brick's location depends on distribution in autoclave machine.

\section{Result and Discussion}

\subsection{XRD Analysis}

X-ray diffraction results are shown in Table 1. Silica sands SS consist of quartz mineral are similar to $100 \%$. It was perfect composition, but reactivity of quartz must be compared with reactivity test. 
Table 1. Chemical major compositions of silica sand (\%) by XRD.

\begin{tabular}{|c|c|}
\hline Silica Sand & Quartz (\%) \\
\hline SS1 & 100 \\
\hline SS2 & 100 \\
\hline SS3 & 100 \\
\hline SS4 & 100 \\
\hline
\end{tabular}

GY3 dan GY4 are mingled with silicon oxide $\left(\mathrm{SiO}_{2}\right)$ in the source more than 5\% as data on Table 2. All of gypsum materials were bothered by its content. Silicon oxide or quartz were obtained from clay on gypsum sources. Purities of gypsum were bothered by its mineral. Mixtures of AAC were influenced by its condition.

Table 2. Chemical major compositions of gypsum (\%) by XRD.

\begin{tabular}{|c|c|c|}
\hline Gypsum & $\begin{array}{c}\text { Gypsum } \\
(\%)\end{array}$ & $\begin{array}{c}\text { Silicon Oxide } \\
(\%)\end{array}$ \\
\hline GY1 & 96 & 4 \\
\hline GY2 & 98 & 2 \\
\hline GY3 & 88 & 11 \\
\hline GY4 & 91 & 9 \\
\hline
\end{tabular}

The data of XRD analysis implies that the mineral compositions of lime samples are inconsistent. The Table 3 shows the major compositions were obtained by XRD Analysis. Calcite in CA3 and CA4 exist on the large amount, $51 \%$ and $72 \%$, respectively. Calcite presents the impurities of samples. Quality of lime was influenced by its mineral and bothered reactivity material while mixing process. The best lime is CA2 with Calcium Oxide at $74 \%$ and no content of calcite.

Table 3. Chemical major compositions of lime (\%) by XRD.

\begin{tabular}{|c|c|c|c|}
\hline Lime & $\begin{array}{c}\text { Calcium Oxide } \\
(\%)\end{array}$ & $\begin{array}{c}\text { Calcite } \\
(\%)\end{array}$ & $\begin{array}{c}\text { Calcium Hydroxide } \\
(\%)\end{array}$ \\
\hline CA1 & 46 & 21 & 32 \\
\hline CA2 & 74 & - & 26 \\
\hline CA3 & 21 & 51 & 7 \\
\hline CA4 & 7 & 72 & 14 \\
\hline
\end{tabular}

\subsection{XRF Analysis}

The chemical composition oxides of raw materials with XRF analysis are listed in Table 4. The number on the material's code indicated different date of material collections. The chemical composition of silica sands SS in different batch and quarry but in the same sources are similar on $\mathrm{SiO}_{2}$ and $\mathrm{Al}_{2} \mathrm{O}_{3}$ content. The averages of its content are $97.46 \%$ and 
$1.02 \%$, respectively. According to data on Table 4, the $\mathrm{SiO}_{2}$ contents are above $97 \%$, but it didn't represent the reactivity of materials clearly.

Table 4. Chemical compositions of silica sand (\%) by XRF.

\begin{tabular}{|c|c|c|c|c|c|c|c|c|c|c|}
\hline $\begin{array}{c}\text { Silica } \\
\text { Sand }\end{array}$ & $\mathrm{Al}_{2} \mathrm{O}_{3}$ & $\mathrm{SiO}_{2}$ & $\mathrm{Fe}_{2} \mathrm{O}_{3}$ & $\mathrm{Cr}_{2} \mathrm{O}_{3}$ & $\mathrm{TiO}_{2}$ & $\mathrm{~K}_{2} \mathrm{O}$ & $\mathrm{CaO}$ & $\mathrm{MgO}$ & $\mathrm{MnO}_{2}$ & $\mathrm{Na}_{2} \mathrm{O}$ \\
\hline $\mathrm{SS} 1$ & 1.10 & 97.25 & 0.15 & 0.01 & 0.15 & 0.18 & 0.06 & 0.10 & 0.01 & 0.14 \\
\hline $\mathrm{SS} 2$ & 0.88 & 97.85 & 0.12 & 0.01 & 0.10 & 0.12 & 0.06 & 0.09 & 0.01 & 0.15 \\
\hline $\mathrm{SS} 3$ & 1.15 & 97.05 & 0.21 & 0.01 & 0.17 & 0.10 & 0.16 & 0.10 & 0.01 & 0.09 \\
\hline $\mathrm{SS} 4$ & 0.96 & 97.67 & 0.15 & 0.01 & 0.03 & 0.15 & 0.05 & 0.10 & 0.01 & 0.14 \\
\hline
\end{tabular}

Gypsum in GY1, GY2, GY3, and GY4, show the different on $\mathrm{CaSO}_{4} 2 \mathrm{H}_{2} \mathrm{O}$ content as listed at Table 5. The amount of its contents are $87.34 \%, 94.22 \%, 77.49 \%$, and $86.72 \%$, serially. The setting time during the solidification process on light-weight bricks were influenced by its content. The data elucidate the inconsistency of the material's quality. According to the data on Table 5, $\mathrm{SiO}_{2}$ and $\mathrm{Al}_{2} \mathrm{O}_{3}$ are present as the composition of all gypsum. Its content indicates the impurities of gypsum and influenced the mixing process.

Table 5. Chemical major compositions of gypsum (\%) by XRF.

\begin{tabular}{|c|c|c|c|}
\hline Gypsum & $\mathrm{Al}_{2} \mathrm{O}_{3}$ & $\mathrm{SiO}_{2}$ & $\mathrm{CaSO}_{4} 2 \mathrm{H}_{2} \mathrm{O}$ \\
\hline $\mathrm{GY} 1$ & 0.64 & 5.18 & 87.34 \\
\hline $\mathrm{GY} 2$ & 0.14 & 2.81 & 94.22 \\
\hline $\mathrm{GY3}$ & 0.36 & 6.69 & 77.49 \\
\hline $\mathrm{GY} 4$ & 0.16 & 2.88 & 86.27 \\
\hline
\end{tabular}

Quality of light-weight bricks were influenced by the usage of lime, which consist of Calcium Oxide $(\mathrm{CaO})$. The $\mathrm{CaO}$ content on $\mathrm{CA} 1, \mathrm{CA} 2, \mathrm{CA} 3$, and $\mathrm{CA} 4$ as present at Table 6 , are $79.52 \%, 85.47 \%, 60.56 \%$, and $61.85 \%$, respectively. The average of its content is $71.85 \%$. CA2 and $\mathrm{CA} 3$ have $\mathrm{CaCO}_{3}$ content, which is higher than $50 \%$, but $\mathrm{CaCO}_{3}$ is natural lime and unreactives to cement and silica sand. Calcium which is unreactives to cement and silica sand, have an effect to compressive strength of AAC in early phase. The overdue in solidification process and crack on early time were caused by its condition.

Table 6. Chemical major composition of lime (\%) by XRF.

\begin{tabular}{|c|c|c|c|}
\hline Lime & $\mathrm{Ca}(\mathrm{OH})_{2}$ & $\mathrm{CaCO}_{3}$ & Total $\mathrm{CaO}$ \\
\hline $\mathrm{CA} 1$ & 60.72 & 9.81 & 79.52 \\
\hline $\mathrm{CA} 2$ & 44.09 & 5.35 & 85.47 \\
\hline CA3 & 30.62 & 53.42 & 60.56 \\
\hline CA4 & 37.71 & 59.42 & 61.85 \\
\hline
\end{tabular}


Alumunium powder is a foaming agent to form hydrogen gas bubbles in mixture. The chemical composition show the dominant content is $\mathrm{Al}_{2} \mathrm{O}_{3}$, higher than $99 \%$ at all as shown in Table 7. Water content on AP2 and AP3 are $26.67 \%$ and $36.72 \%$, but for AP1 is only $0.36 \%$. Alumunium powder is reactive material. The reactiveness of aluminium powder in mixture were influenced by water content and storage humidity related to stock up duration.

Table 7. Chemical major compositions of aluminium powder (\%) by XRF.

\begin{tabular}{|c|c|}
\hline $\begin{array}{c}\text { Alumunium } \\
\text { Powder }\end{array}$ & $\mathrm{Al}_{2} \mathrm{O}_{3}$ \\
\hline AP1 & 99.57 \\
\hline AP2 & 99.49 \\
\hline AP3 & 99.37 \\
\hline
\end{tabular}

\subsection{Reactivity Test}

The quality of AAC related to mineralogical composition, and texture were influenced by the composition and reactivity of raw materials. Reactivity tests were applied to pozzolanic materials $[11,12]$, and were indicated by its compressive strength at 7 days. The result of reactivity of raw material SS is illustrated in Fig.5.

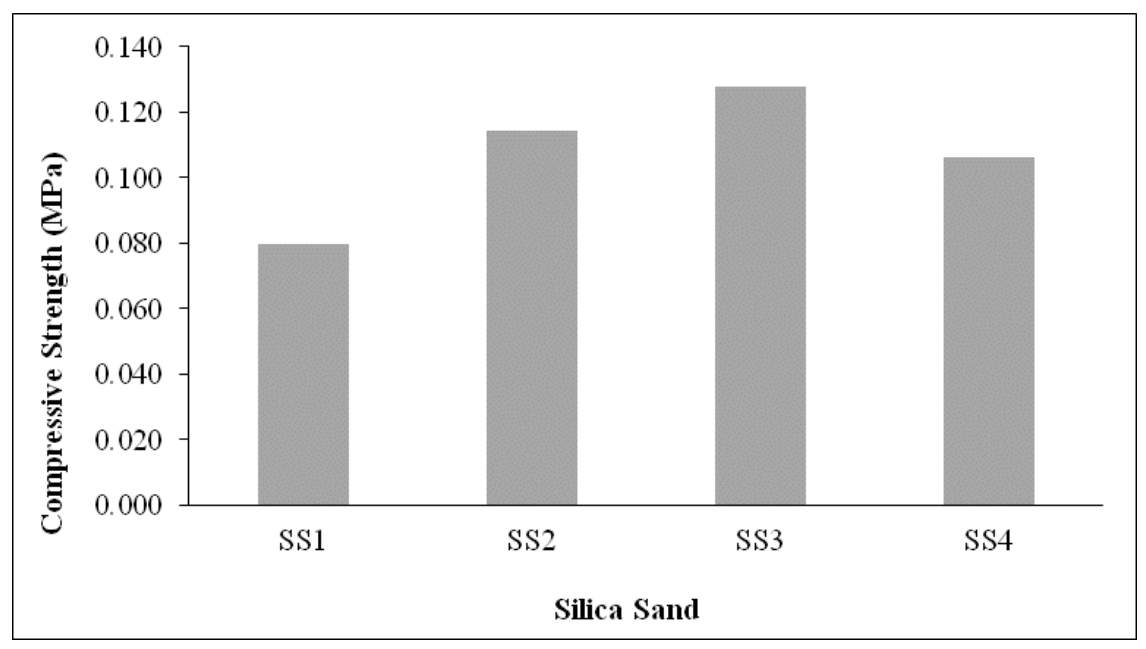

Fig. 5. Compressive strength of silica sand's reactivity.

Generally, Fig.5 described that silica sands as raw material is unreactives. Bonded of silica sand to cement and lime were influenced by its particle size. Coarses particle were indicated that silica sand in AAC composition only as filler and unreactives. Fig.5 shows that SS3 is the best reactive silica sand with $0.128 \mathrm{MPa}$ of compressive strength. By its condition, the improvements were applied. The SS3 was chosen as material in the next experiment. The best silica sand SS3 was grinding to be SSH by 2-4 hours and compared with fly ash FA to replace the ordinary silica sands (OSS) by $5 \%, 10 \%$, and $15 \%$. Its results are shown in Fig. 6. 


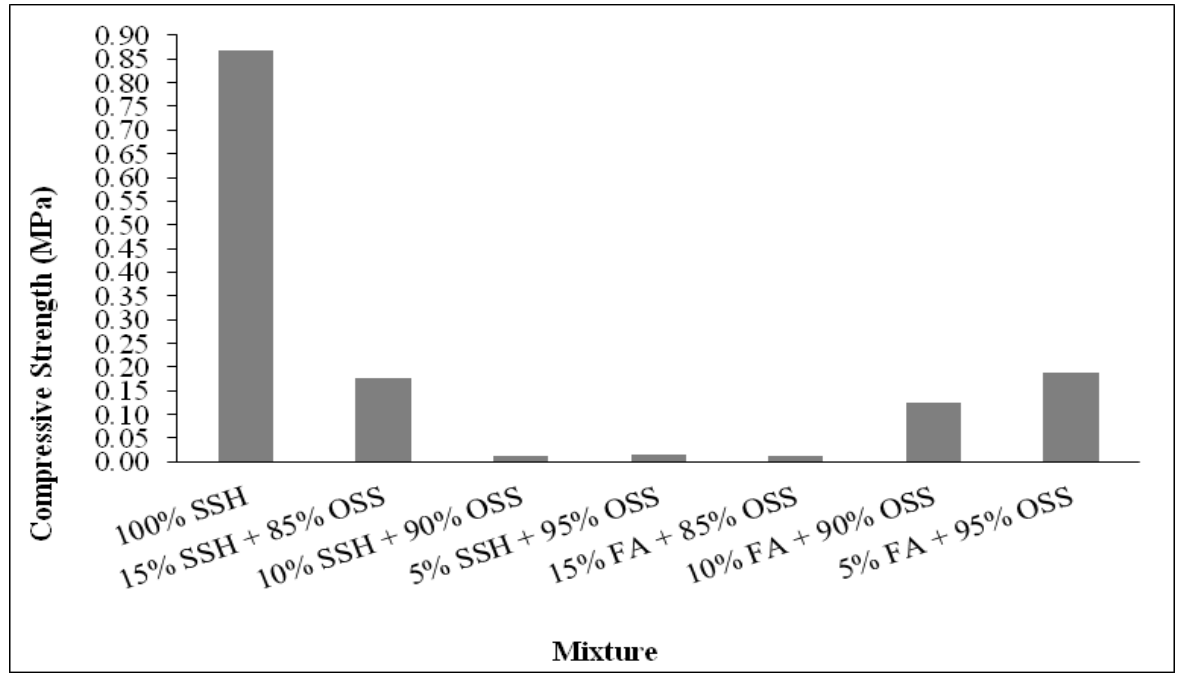

Fig. 6. Compressive strength of recommendation mixture.

From the data above in Fig.6, 100\% OSS replaced by SSH shows the best result of compressive strength, and follows by $5 \%$ OSS replaced by FA in mixture. Grinding the sands contributes to increase the reactivity of mixture to be more than five times. The data illustrated that the compressive strength increase while the fineness increase. It implies that finer quartz content in silica sands and fly ash, increases the compressive strength of reactivity materials. The finer quartz which has higher surface area could supply larger amounts of dissolved silica. It was same occurred on cement paste partially replaced by fly ash [13] and relationship of fineness and surface area [14]. The utilization of fly ash reduced the amount of silica sands in mixture. The content of silica and alumina in fly ash increased the stiffness of AAC. The utilization of fly ash easier than grinding the silica sand, because it's no need extra machine and time. The fly ash can be used as the alternative siliceous raw materials for the production of AAC [15]. Fly ash were also obtained during AAC productions in industry, but it needs further analysis to determine the class of fly ash.

\subsection{Compressive Strength Based on Distribution in Autoclave Machine}

The differentiation of compressive strength was influenced by the distribution of specimens in autoclave machine. In this analysis, the strength based on the distribution of light-weight bricks in autoclave machine were observed at 28 days. Samples were collected from four autoclave machines, namely $\mathrm{AC} 1, \mathrm{AC} 2, \mathrm{AC} 3$, and $\mathrm{AC} 4$, in different position as Fig. 4. Before autoclaving process, AAC were prepared as Fig. 7. 


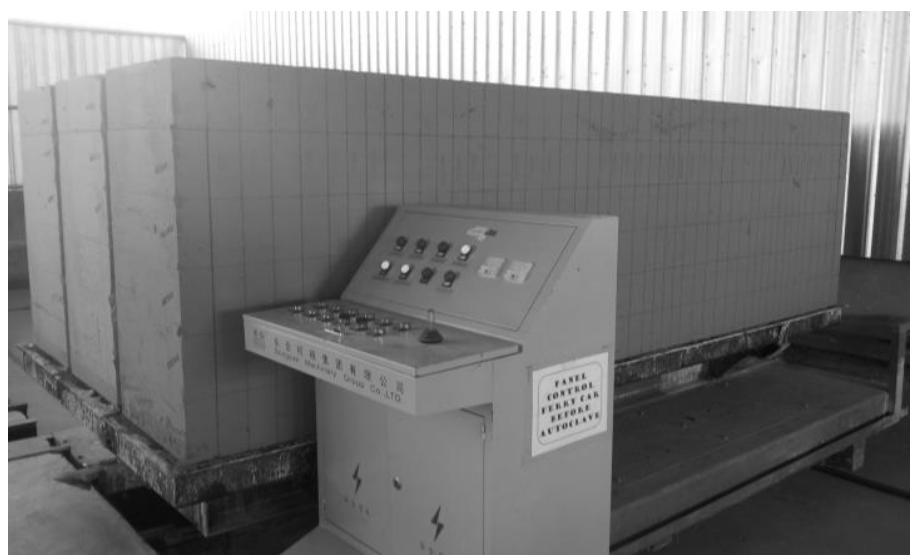

Fig. 7. Preparation before autoclaving process.

Generally, the quality related to compressive strength is supported by the maturity of AAC samples. The data were illustrated in pattern as Fig.8-11.

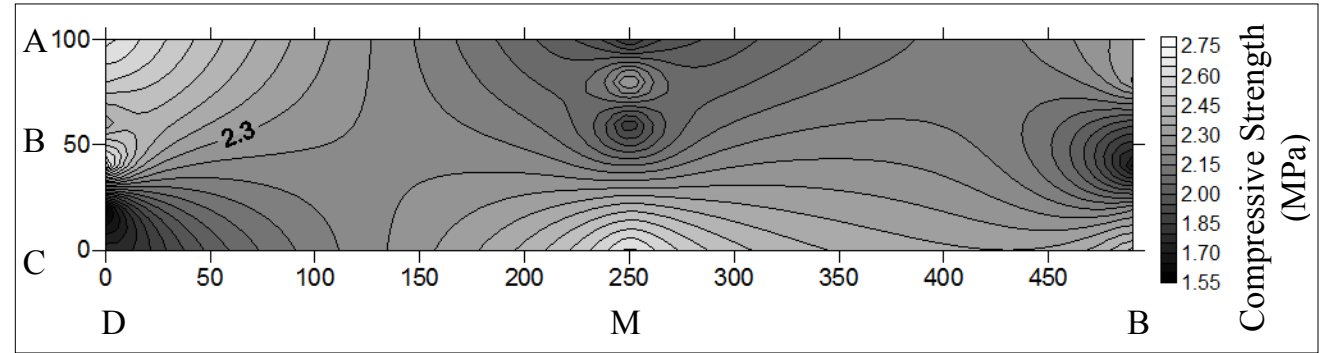

Fig. 8. Contour of compressive strength in autoclave machine AC1.

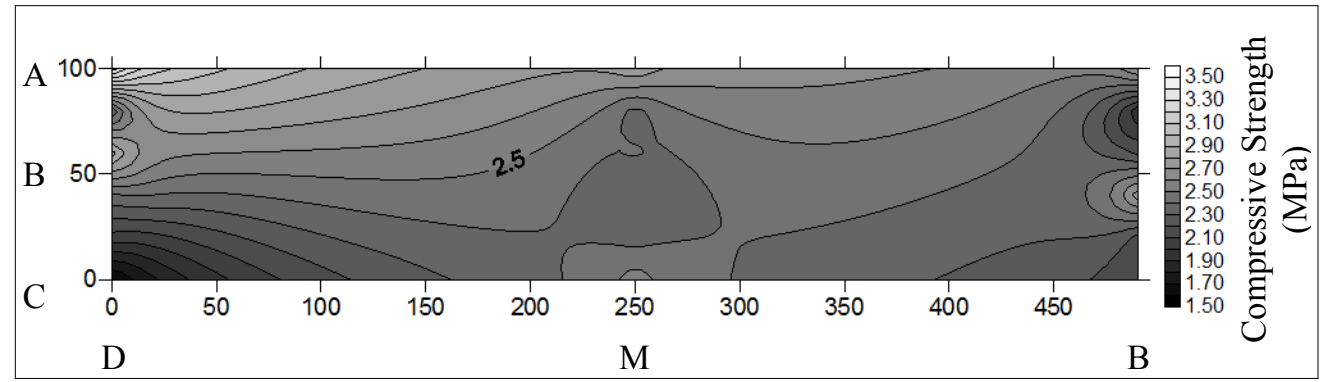

Fig. 9. Contour of compressive strength in autoclave machine AC2.

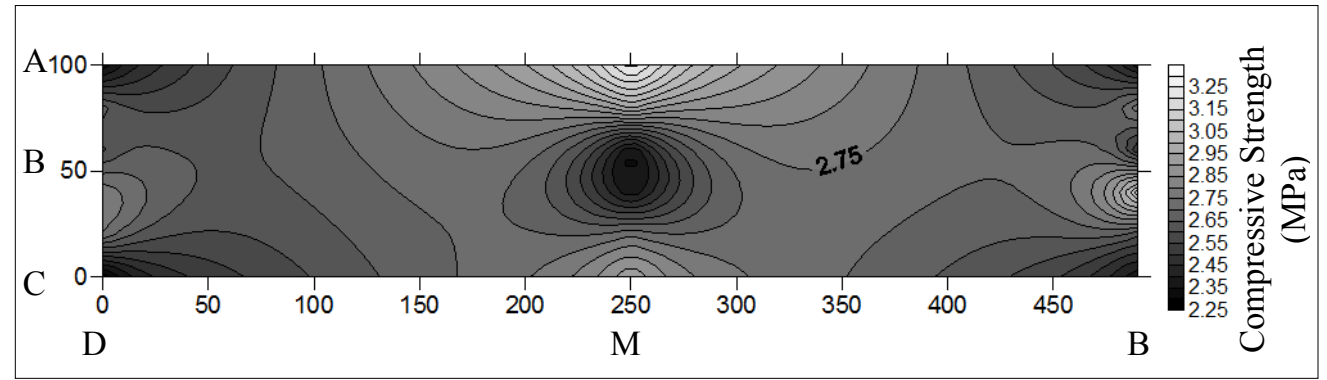

Fig. 10. Contour of compressive strength in autoclave machine AC3. 


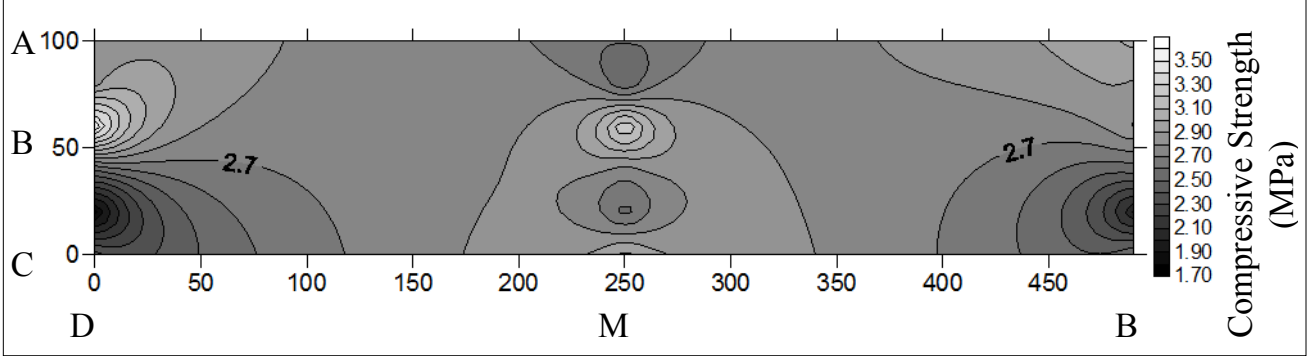

Fig. 11. Contour of compressive strength in autoclave machine AC4.

The strength of AAC samples are similar on AC1, AC2, AC3, and AC4. The averages are 2.22 MPa, 2.41 MPa, 2.65 MPa, and 2.71 MPa, respectively. The highest compressive strength was occurred in AC4, and the lowest was found in AC1. The patterns in Fig. 8-11 indicate variety of AAC quality based on the distribution of samples in autoclave machine during curing process. According to the pattern in Fig. 8 and Fig.11, AC1 and AC4 indicate the similar condition. Up-side position contributes the higher compressive strength than back and below-side. Darker pattern represents the smaller strength. Its conditions were found at all autoclave machines, especially closed to the door. It was caused by inconsistency of autoclave machine pressure. The darker patterns in AC1 and AC3 are shown at the center of machine were caused by the composition and maturity of AAC samples. The pattern of compressive strength related with the distribution of samples in autoclave machine represents the pressure quality during the autoclaving process. It needs maintenance process to keep the machine in proper condition. Physical properties of products were caused by its conditions and supported by mineralogical composition and reactivity of raw materials. It was agreed with Hausser et al [6].

\section{Conclusion}

1. The raw material which is used in this experiment were inconsistent in quality, even they were taken in same source and quarry.

2. Source and storage system affect the moisture of the raw materials. It will cause the difference of material's quality.

3. The compressive strength according to reactivity of materials is more affected by material's fineness and surface area.

4. Replacing ordinary silica sand with $100 \%$ finer silica sands in amount deliver the best reactivity and compressive strength. But the extra time to grinding silica sand were needed by $2-4$ hours.

5. Replacement of silica sand with 5\% FA is the optimum recommendation as it shows the high compressive strength without extra time. Reactivity materials increases the quality of AAC products.

6. The utilization of fly ash as by-product materials in autoclaving process during AAC production reduce the problem with waste, but it need further analysis according to the class of its fly ash.

7. The compressive strength related to the distribution of samples in autoclave machine represents the pressure quality during autoclaving process and the quality of autoclave machine. The maintenance of autoclave machine should do regularly.

8. Physical damage of products were caused by machine conditions and supported by mineralogic composition and reactivity of raw materials. Furthermore, maintaining quality of raw materials, curing process, and maintaining the machine will either reduce the product damage that occurred during the fabrication process in industry. 
This research has been supported by Lembaga Penelitian dan Pengabdian Masyarakat ITS (LPPM ITS) and Lembaga Pengelola Dana Pendidikan Republik Indonesia (LPDP RI).

\section{References}

1. K. Kunchariyakun, S. Asavapisit, K. Sombatsompop, “Cem. Con. Comp.”, 55, 11 (2015)

2. Y. Song, B. Li, E.H. Yang, Y. Liu, T. Ding, “Cem. Con. Comp.”, 56, 51 (2015)

3. M. Sinica, G.A. Sezeman, D. Mikulskis, M. Kligys, V. Cesnauskas, "Const. Build. Mater.,, 50, 718 (2014)

4. K. Matsui, J. Kikuma, M. Tsunashima, T. Ishikawa, S. Matsuno, A. Ogawa, M. Sato, “Cem. Con. Res.", 41, 510 (2015)

5. N. Isu, H. Ishida, T. Mitsuda, “Cem. Con. Res.”, 25, 243 (1995)

6. A. Hauser, U. Eggenberger, T. Mumenthaler, “Cem. Con. Res.”, 29, 297 (1999)

7. G. Schober. ZKG Int., 58, 63 (2005)

8. R. Drochytka, J. Zach, A. Korjenic, J. Hroudová, “En. Build”., 58, 319 (2012)

9. O. Koronthalyova, “Const. Build. Mater.”, 25, 879 (2011)

10. A. Laukaitis, J. Keriene, D. Mikulskis, M. Sinica, G. Sezemanas, "Const. Build. Mater.", 23, 3034 (2009)

11. American Society of Testing and Materials C593-95, Standard Spesification for Fly Ash and Other Pozzolans for Use with Lime, United States, (2000)

12. JJ. Ekaputri, H. Limantono, Triwulan, T. E. Susanto, M. M. A. B. Abdullah, "Key. Eng. Mater.”, 673, 83 (2016)

13. P. Chindaprasirt, C. Jaturapitakkul, T. Sinsiri, “Cem. Con. Comp.”, 27, 425 (2005)

14. R. Nurwidayati, M.B. Ulum, J.J. Ekaputri, Triwulan, P. Suprobo, "Mater. Sci. Forum”, 841, 118 (2016)

15. N. Huberman, D. Pearlmutter, "En. Build". 40. 837 (2008)

16. L.N. Halim, J.J. Ekaputri, "Mat. Web. Conf.”, 97, 01002 (2017) 